\title{
Transgovernmental Networks as an Apprenticeship in Democracy? Socialization into Democratic Governance through Cross-national Activities ${ }^{1}$
}

\author{
Tina FReyburg \\ The University of Warwick \& ETH Zurich
}

\begin{abstract}
Does contact with democratic governance make state officials in authoritarian regimes more democratic? While studies of democratic diffusion are built on the inherent assumption that exposure to democratic practices shapes the attitudes of domestic actors toward democracy, scholars of international socialization are more skeptical about such micro-effects. Drawing on insights from sociology and social psychology, I examine what type of cross-national activities can socialize Moroccan state officials into democratic governance. The results of cross-sectional, multivariate regression analyses based on original survey data emphasize that, in authoritarian contexts, transnational linkage manifests the potential to democratize only if it involves practical experience, a condition fulfilled by cooperative exchange within transgovernmental networks, but not by more diffuse types of linkage such as international education and foreign media broadcasting.
\end{abstract}

Transnational interchange is widely expected to form channels of ideological diffusion, changing the attitudes if not the behavior of domestic actors turning them into democratically minded agents within predominantly nondemocratic environments (Levitsky and Way 2005; Simmons, Dobbin, and Garrett 2006). Studies of democratic diffusion statistically demonstrate that the strength of transnational ties to democracies is systematically correlated with democracy (Kopstein and Reilly 2000; Cederman and Gleditsch 2004; Doorenspleet 2004). However, as they use comprehensive predictors such as geographic proximity, which are only proxies for an assortment of transnational interchanges, these macro-level studies neglect to explicitly test the theoretical micro-foundation of their argument, that is, the actor-specific causal mechanisms underpinning theories of diffusion on the aggregate or country-level. The few existing micro-level studies appear to present a diverse picture in terms of the effect produced. Since each is limited to one specific type of influence, most prominently foreign media use (for example, Kern and Hainmueller 2009), migration to Western democracies (for example, Pérez-Armendáriz and Crow

Tina Freyburg is an assistant professor in the Department of Politics and International Studies at the University of Warwick/United Kingdom and an affiliated researcher in the Centre for Comparative and International Studies at ETH Zurich/Switzerland. In her research, she explores new avenues in the study of democratization and EU external relations.

${ }^{1}$ An Online Appendix containing supplemental information on the analyses and additional robustness checks can be downloaded from the author's website (www.tina-freyburg.eu). The corresponding replication material including data set and $\mathrm{R}$ code is freely available from the author upon request. I thank, in particular, Tobias Böhmelt, Stephen Krasner, Sandra Lavenex, Chris Reus-Smit, Thomas Risse, Frank Schimmelfennig, Vera Troeger, and Eva Wegner for valuable comments. I also appreciate the detailed comments and suggestions from the three anonymous reviewers and the editor of International Studies Quarterly, which helped to improve the article significantly. I would like to express my gratitude to the numerous European and Moroccan officials who made this study possible. Financial support from the Swissfunded NCCR Democracy and the Leverhulme Trust Foundation is gratefully acknowledged.
2010), or international education (for example, Atkinson 2010 ), they cannot provide illumination as to which types of transnational influence actually yield democratic socialization. Hence, despite the growing body of research on democratic diffusion through transnational linkages, we know little about whether and under what conditions cross-national activities socialize individuals in authoritarian contexts into democratic principles and practices. Motivated by this puzzle, this article aims to advance our understanding of the democratization effects of transnational linkages at the micro-level of individual attitudes.

Enriching research on international socialization and democratic diffusion with insights from sociology and social psychology, I theorize that exposure is more likely to shape individuals' attitudes the more their experiences take place in a targeted, structured, and interpersonal setting. Specifically, I expect transnational exchange to successfully socialize state officials from nondemocratic regimes into democratic governance only when it implied direct contact and provided the opportunity to practice. Accordingly, participation in transgovernmental networks should have a stronger attitude-shaping effect than more diffuse types of transnational activities such as international education and foreign media broadcasting. In contrast to these traditionally examined types, networks offer state officials in nondemocracies possibilities to practice democratic governance in day-to-day administrative routines and to discuss potential ambiguities in direct exchange with their counterparts from state administrations in established democracies. I scrutinize this argument empirically by exploiting an original data set on attitudes toward democratic governance that I created on the basis of a survey I conducted among 150 Moroccan state officials; qualitative interviews and answers to an open survey question demonstrate the plausibility of the argument.

By looking at state officials rather than the political elite or citizens, a group of actors is selected which plays a crucial role in sustaining authoritarian rule or eventually implementing democratic change from within the 
regime. In this, the presented research addresses Marsh's (1971:464) plea to study the attitudes of those individuals that can directly influence the "operation of the political system." Eventually, a state's administrative staff is important for both the stabilization of an authoritarian regime and the consolidation of democratic institutions. First, in any political system, the administrative staff, as government in action, is the body entrusted with formulating and implementing policy, thus carrying out government decisions (Farazmand 2010). The capacity of an authoritarian regime to impose and maintain nondemocratic rule is, among others, defined by its ability to "control political outcomes and consolidate [...] political order" (Way 2005:232). Internal state control then includes the extent to which state officials obey orders. A reform-oriented, democratic-minded administrative staff might undermine authoritarian state control if opportunities emerge to circumvent or ignore central commands. Second, state officials represent that part of the public sector which citizens actually have contact with and may shape their perceptions of how the political system functions. The democratization literature acknowledges that in order to be fruitful, democratic reforms at the polity level require state officials familiar with democratic modes of governance. Otherwise, democratization processes risk resulting in "enlightened dictatorship" (Baker 2002:5) that circumvents rather than allows effective democratic control by the citizens when used by specific classes and oligarchies to control political power and sustain ineffective, corrupt regimes.

The study of attitudes provides new insights regarding the democratic impact of inter-administrative cooperation beyond the formal-legal basis of public administration. Importantly, I would not want to equate positive attitudes toward democratic governance of state officials in authoritarian regimes with pro-democratic regime change. It would be naif to believe that if state officials could only learn to understand and appreciate democratic ways of policymaking, authoritarian ruling gave way to democratic government. Yet, although the long-term effects are difficult to estimate, it can be reasoned that pro-democratic administrative staff can play an important part in creating the conditions for democratic regimechange and democratic consolidation. This might be especially true in Arab authoritarian regimes, most notably in bureaucratic monarchies such as Morocco, which attach great importance to state bureaucracy for the maintenance and stability of the regime.

The political culture in Morocco is generally shaped by an "absolute authority" (Zerhouni 2004:62) around the central power of the makhzan, the monarchy, and its hegemonic state apparatus. Yet, the middle level of administrative hierarchy is evolving toward modernization (Al-Arkoubi and McCourt 2004); the state officials employed are increasingly recruited with regard to their professional specialization and "controlled with more difficulty by the traditional means of makhzenian command" (Claisse 1987:54). It is these officials who make up the target group of this study, as they represent promising stakeholders for democratic change. They are important in the transformation of a political regime, and changing their attitudes can be seen as one potentially important step in the complex and multifaceted process of creating the conditions for democratic government.

This article contributes to the development of microfoundations for comparative research on democratic diffusion. The analysis of micro-effects of three different forms of transnational interchange (international education, foreign media, transgovernmental networks), based on original survey data and interviews, allows to identifying the type of linkage between democracies and nondemocracies that can actually unfold the potential for democratic socialization. The results demonstrate that, in line with my expectation, transgovernmental networks have a stronger and more positive effect on the attitudes of state officials toward democratic governance than commonly considered linkages, notably international education and foreign media.

\section{Transnational Influences and Democratic Socialization}

My theoretical starting point is the constructivist work on socialization in International Relations in which international institutions are seen as constituting a "site of socialization" (cf. Johnston 2001; Checkel 2005:807). I adopt the idea that actors embedded in international institutions can become acquainted with community-shared norms as a consequence of social interaction and apply it to the transfer of democratic governance in the transnational realm. I thereby bridge two strands of literature in International Relations that have remained somewhat distinct, namely the literature on international socialization and that on democratic diffusion. Considering that both strands are ultimately built on the assumption that exposure to transnational norms has an attitude-shaping effect toward these norms, the bridge is built by bringing socialization into democratic governance as a consequence of exposure via transnational linkages to the core of the analysis.

As regards democratic diffusion, I provide a differentiated analysis by comparing different kinds of transnational exchange and examining both the independent and interaction effects they might have on individuals' attitudes. Building upon literature that emphasizes the democratization through cross-national activities, I explore the effect of conventionally analyzed linkages, international education and foreign media, and adjoin a widely disregarded type, specifically transgovernmental networks. This comparative approach is based on the reasoning that, first, not all transnational linkages are the same but present different types of exposure, and, second, different types might exert influence at the same time and interfere with each other.

I adopt an approach to international socialization that differs from existing research in three regards. First, I develop a perspective that cuts across the two predominant strands of research on international socialization-socialization through and socialization in international institutions - and unites the more promising aspects. Second, I apply a definition of socialization as attitude change that is anchored in social psychology and departs from a narrow understanding of internalization. Third, I select an empirical case that allows me to confidently measure international rather than national socialization. I propose that these three conceptual modifications enable me to capture socialization effects that have previously been disregarded, as will subsequently be outlined.

First, research on international socialization can be classified into two predominant strands. The first strand analyzes the transfer of transnational norms but considers socialization as the outcome of direct promotional efforts of external actors at the level of the state (government) (Finnemore 1993; Risse, Ropp, and Sikkink 1999; Flockhart 2004). The second strand views international institutions as sites of socialization but is predominantly 
interested in identity transformation on the part of individuals delegated to international organizations (Kerr 1973; Checkel 2005; Hooghe 2005). My research integrates both branches as it views transnational influences as creating a site of socialization but concentrates on changes in attitudes toward democratic governance. In contrast to earlier research on international micro-socialization, in the present study, democratic socialization implies no changes of loyalty or identity touching upon the core of an individual's personality. Instead, it refers to principles and practices that belong to the professional realm of state officials and are introduced as side effects of transnational interchange (rather than by straightforward promotion strategies), which, I assume, facilitate socialization. While transnational influence can be diffuse such as in the case of foreign media broadcasting, the acquisition of new knowledge and the internalization of new standards of behavior is a reflexive activity.

Second, I define democratic socialization as being present to the degree that individuals change their attitudes toward democratic governance through exposure to transnational influences. This definition largely corresponds to the sociologist understanding of socialization as "social process through which agent properties and preferences change as a result of interaction" (Checkel and Moravcsik 2001:220). Yet, by referring to socialization as the outcome rather than the process of socializing or both, my understanding departs from this classical one. ${ }^{2}$ In addition, I distance myself from the ambitious target of measuring "internalization" or "full socialization," which "implies that agents adopt the interests, or even possibly the identity, of the [socializing] community" (Checkel 2005:804) and ascribe them a "taken-forgranted" quality. Instead, I draw on social psychology and apply a two-dimensional understanding of attitude change (Zimbardo and Leippe 1991:31; Eagly and Chaiken 1993). Attitude change refers not only to affective change like increased agreement and support, where actors internalize democratic modes of governance as appropriate in specific situations ("Type I socialization," Checkel 2005:804). It also covers influences at the level of cognition: actors acquire new knowledge leading to a change in their "factual beliefs," which is their knowledge about the meaning, prerequisites, performance, and other attributes of democratic governance ("Type II socialization," Checkel 2005:804). Although this distinction is analytically important, a difference in mechanisms (internalization vs. learning) and outcomes (affective vs. cognitive changes in attitude) is not discernible in this study. Since principles of democratic governance are rather abstract and unlikely to be supported (and reported) without being understood, I assume that, first, affective attitude change presumes prior cognitive processes, and, second, that individual attitudes toward democratic governance can, to a large extent, be summarized as one-dimensional. This corresponds to earlier research that conceptualized socialization as "both cognitive learning and at least minimal internalization of appropriate norms" (Moore 1969:868). The presented study captures subliminal effects of external influences in authoritarian contexts where exposure may shape attitudes toward democratic governance but trigger no automatic behavioral realization in view of likely negative consequences,

\footnotetext{
${ }^{2}$ For an excellent discussion of the "product-process ambiguity" inherent in studies of socialization and the problématique in defining socialization as "internalization," see Long and Hadden (1985), Beyers (2010).
}

such as being transferred to less attractive positions or losing the job.

Finally, studies of individual-level socialization demonstrate that the socialization effect observed appears to be rooted in experiences at the national rather than international level. The most prominent example is research on socialization as a process making participants in international organizations more "international" or "European" in outlook. It is demonstrated that support for supranational norms is relatively high but more because of selfselection or selective recruitment: National delegates sent to international organizations tend to already be proEuropean or cosmopolitan before they start working at the supranational level (Pollack 1998; Beyers 2005; Hooghe 2005). Existing studies tell us little about whether people are socialized once they are exposed to transnational norms but more about who is actually appointed as national delegate to international organizations. I will turn later to this important point when presenting the research design and discussing this study's implications. For the moment, it shall suffice to emphasize that, in contrast to most existing work on international socialization, this study explores a case where national socialization should generally work against transnational socialization and minimize rather than increase any observable effect. The attitudes of state officials employed by a stable authoritarian regime can be assumed to be nondemocratic in the absence of any external influences (Bova 1991:129).

\section{The Independent Socialization Effect of Transnational Influences}

Studies of democratic diffusion point to the importance of international education and foreign media as transporters of democratic principles and practices across borders. A number of democracies actively finance foreign education (for example, the U.S. Fulbright Program or the German Academic Exchange Service) and foreign media broadcasting (for example, Radio Free Europe/ Radio Liberty or Voice of America) in the hope of promoting liberal norms such as human rights, democracy, and gender equality. These policies risk having the opposite effect of strengthening authoritarian regimes, as some studies have pointed out. For instance, if foreign media were used primarily as a source of entertainment, then it increased public support for the East German communist regime by "making life under communism more bearable and the East German regime more tolerable" (Kern and Hainmueller 2009:378). Moreover, exposure to foreign media may highlight the malfunctioning of democratic bureaucracies and demonstrate how democratic control of bureaucratic acts can irritate state officials individually. Anecdotal evidence on foreign-educated leaders, in turn, suggests that studying in liberal democracies can lead to the rejection of liberal values such as in the example of Sayyid Qutb, the Islamic fundamentalist leader, whose experiences as a student in the United States (US) are said to have reinforced his belief in the moral decay of Western civilization (Spilimbergo 2009:530). In this study, however, I concentrate on the potential of transnational influences to socialize domestic individuals into democratic governance in authoritarian contexts.

Study visits in a democratic country allow citizens of nondemocratic states to experience democratic decisionmaking firsthand. Transferred to the focus of this study, state officials' understanding of appropriate governance 
is likely to be influenced by personal experiences of democratic governance when studying abroad for a considerable period of time. "Through the exchange experience, participants (who may have little exposure to democratic norms and ideas) observe how people behave within a democratic system, acquire knowledge about how democracy [and democratic governance] functions, and learn what to expect of their own leaders and institutions" (Atkinson 2010:2). Based on these arguments, I derive a first hypothesis on the independent effect of international education:

Hypothesis 1: State officials are more likely to have a positive attitude toward democratic governance when they have studied in a democratic country.

Officials can also become acquainted with democratic governance at home if they use foreign media for political information. The view that Western broadcasting nurtures pro-democratic attitudes and undermines public support for authoritarian regimes is widely shared (Norris 2004; Levitsky and Way 2005; Kern and Hainmueller 2009). Yet, "our understanding of mass media's contribution to the process of learning new attitudes during democratic transition [let alone in times of stable authoritarianism] has gone largely unexamined" (Loveless 2009:110). Exposure to foreign media is expected to familiarize state officials with democratic governance by confronting them with media content that delineates administrative practices in established democracies, exemplifies the involvement of the public in these processes, and reports on infringements against democratic governance. The hypothesis on the independent effect of foreign media reads:

Hypothesis 2: State officials are more likely to have a positive attitude toward democratic governance when they regularly use Western media for political information.

In addition to these two conventional transnational influences, I propose to probe into an alternative factor: transgovernmental networks. Transgovernmental networks can possibly trigger processes of democratic socialization as they provide a stage for social interaction and professional exchange among peers (Keohane and Nye 1974:39; Slaughter and Zaring 2006:214; Freyburg 2011). They bring specialists from the administrations of both established democracies and authoritarian regimes "as individuals, together on a repeat basis" (Raustiala 2002:55). Transgovernmental networks are meant to implement policy solutions and carry out legal requirements based on the standards of the administrations of the more developed countries that in most cases happen to also be more democratically constituted. The standards refer not only to substantive rules for regulating policy but also incorporate procedural rules on how decisions are to be made. Given that these procedural rules were developed for advanced democracies, in principle they embody elements of democratic governance (Freyburg, Lavenex, Schimmelfennig, Skripka, and Wetzel 2011). Since bureaucrats from Western countries are professionally socialized in a democratic polity, it is assumed that they apply and impart democratic governance when serving as experts abroad. As part of their advisory service, they address issues suppressed in domestic discourse such as the participation of nonstate actors in administrative decision making and the availability of information to the public. By participating in cooperative activities, state officials become introduced to democratic governance unknown under authoritarian rule. This assumption is corroborated by earlier studies that explored qualitatively whether national agents in Eastern candidate states became socialized into a set of liberaldemocratic security norms due to their participation in exchange programs created by the National Atlantic Treaty Organization (NATO) (Flockhart 2004; Gheciu 2005). Based on the above considerations, I formulate a third hypothesis on the independent socialization effect of participation in transgovernmental policy networks:

Hypothesis 3: State officials are more likely to have a positive attitude toward democratic governance when they have been involved in transgovernmental policy networks.

\section{The 'Contact Hypothesis' and Democratic Socialization}

The idea that transnational interchange between established liberal democracies and authoritarian regimes socializes the latters' bureaucrats into democratic governance is based on the assumption that people are socially influenced by what other people think and do. However, studies on international socialization (Beyers 2005; Hooghe 2005) and policy networks (Marsden 1990; Van Waarden 1992) find only weak support for the contact hypothesis if duration is used as a proxy for contact. They conclude that contact alone represents a necessary condition for socialization and suggest that more substantial factors concerning the quality of contact are needed to measure socialization effects.

This proposition nicely echoes social-psychological work. Research on processes related to prejudice, discrimination, and racism underscores the importance of interpersonal contact in changing attitudes. It has provided empirical evidence "that, although the contact-attitude link is not large, intergroup contact typically improves attitudes toward both the specific individuals involved in contact and the outgroup as a whole" (Paolini, Harwood, and Rubin 2010:1723). Scholars exhaust Allport's (1954) influential work on the "contact hypothesis," which originally specified four critical situational conditions for intergroup contact, synthesized as "equal group status within the situation; common goals; intergroup cooperation; and the support of authorities, law, or custom" (Gaertner, Dovidio, and Bachman 1996:272). The contact hypothesis has been extended to include the effect of indirect forms of contact on attitudes such as mass media contact. "Parasocial contact" is said to provide similar experiences to interpersonal contact, but only if media products can give "the illusion of face-to-face relationship with the performer" (Schiappa, Gregg, and Hewes 2005:93). In any case, studies by social and cross-cultural psychologists indicate "that superficial contact reduced to trivialities instead of meaningful communication" (Sigalas 2010:248) is unlikely to shape attitudes. Importantly, in their meta-analysis of studies on the contact hypothesis, Pettigrew and Tropp (2000) demonstrate that not all conditions need to be present simultaneously to shape attitudes. However, the more conditions are present, the more likely it is that a successful and lasting outcome will be achieved. The set of conditions identified can be transferred to a broader understanding of contact in terms of exposure to transnational influences 
that encompasses both personal and impersonal contact. This expectation is corroborated by explanations grounded in sociology that point to the importance of practices in explaining social action. Here, social action is often realized through "doing" rather than normative compliance (Rohrschneider 1996) or practical knowledge (Pouliot 2008). Based on this reasoning, I expect that different kinds of transnational linkage produce democratic socialization to a varying extent.

Providing structured contact targeted at the transfer of rules originated in democracies, transgovernmental networks fulfill the criteria best. These networks are created in order to implement cooperation that is requested by authoritarian elites seeking effective solutions to policy problems. This objective can only be reached if external and domestic officials act in concert and exchange at eyelevel. Visiting officials are often presented as "teachers," but the local staff knows the domestic conditions best. Contact in the framework of international education is, in turn, less structured and targeted (Merritt 1972). Study visits to democracies generally provide acquaintance potential as students' daily lives take place in the culture and social structure of a democracy. The selection of interpersonal contacts is, however, up to them, and the extent to which they experience democratic governance is unknown. It might well be the case that social contact is limited to other foreign students with a similar socialization background. Foreign media broadcasting presents the least structured and targeted form of transnational influence because it does not necessarily provide the illusion of face-to-face contact. It is likely that state officials filter media products and accept only those pieces of information that fit into their familiar schemata of appropriate ways to make and implement policy decisions, as suggested by the "filter hypothesis" in research on media effects on individual voting behavior (SchmittBeck 2003:2589). Moreover, Western media tend to center on the pitfalls of bureaucracy rather than the advantages of democratic rule. Passive media consumption does not necessarily provide the possibility of dealing with cognitive dissonances and problems of comprehension in an interactive and cooperative interpersonal setting. I therefore expect a stronger socialization effect if state officials have had contact with principles of democratic governance in a structured and targeted interpersonal manner:

Hypothesis 4: State officials are more likely to have a positive attitude toward democratic governance when they have participated in policy networks than when they use foreign media or have studied in a democracy.

The socialization potential of transgovernmental networks might be boosted by the influence of other transnational influences. Studies in psychology in the 1970s and 1980s identify the "repetition effect" as being crucial for attitude change to occur. They found that repetitive exposure facilitates the familiarization of individuals with complex arguments, as "the repetition of the message arguments provide[s] more opportunities to elaborate cognitively upon them and to realize their cogency and favorable implications" (Cacioppo and Petty 1979:105). Following this line of reasoning, state officials who have had prior experiences with principles of democratic governance may be expected to be better disposed to change their attitudes when reexposed. To give an example, officials might need to have cognitively learned about democratic governance via various channels such as a stay abroad (but not necessarily appreciate democratic practices) so that subsequent exposure in the form of targeted interpersonal exchange within transgovernmental networks can build on this knowledge and put it into a (more) favorable light. I hypothesize that the likelihood of democratic socialization increases with the recurrence of exposure to democratic governance:

Hypothesis 5: State officials that have participated in transgovernmental networks are more likely to have a positive attitude toward democratic governance when they had previously experienced democratic governance.

\section{Research Design}

The question of whether transnational influences yield processes of democratic socialization is tested by means of multiple regression analyses on cross-sectional data from a survey among 150 Moroccan state officials that I conducted over 3 months during the summer of 2008. In terms of generalizability, Morocco is both a hard and a most plausible country case to explore this question. It is hard because, at the time of this study, Morocco has had one of the world's most durable authoritarian regimes. The few low-level reforms such as the introduction of elections were "of little consequence in determining who will really rule" (cf. Brumberg 2002; Diamond 2010:95). The Kingdom of Morocco thus presents a country case that allows for a separation of external influences from domestic dynamics, as democratic socialization is unlikely to happen in the absence of influences from the outside. But within the world of (Arab) authoritarian regimes, Morocco may be a most plausible case because it has been the most exposed culturally, economically, and politically to Western democratic norms. Hence, if transnational influences shape the attitudes of (intermediate-level) state officials in authoritarian regimes, then such an effect should occur in the present case. Correspondingly, if there is little evidence of socialization here, there is little hope for socialization anywhere in the near-abroad.

The survey data contain responses from 98 males and 52 females; the mean age is 41 with lower and upper quartiles of 25 and 57. Respondents could choose the language of communication, French or Arabic; 9\% chose the Arabic version. The closed-ended questionnaire was cognitively pretested on knowledgeable experts (Presser, Rothgeb, Couper, Lessler, Martin, Martin, and Singer 2004). Personal distribution on site enabled a response rate of approximately $96 \% .^{3}$ To determine the effect of transnational influences on the attitudes of Moroccan state officials toward democratic governance, I apply a "static-group comparison design" (Campbell and Stanley 1963:12). That is, I statistically compare the attitudes of two groups of state officials at a single point in time, one of whom has received the "treatment" 4 (here: exposure to transnational

\footnotetext{
${ }^{3}$ Only one official flatly refused to fill in the questionnaire; fewer than five officials could not be reached because of professional commitments abroad or vacation.

${ }^{4}$ Various authors refrain from using the term "treatment" when referring to quasi-experimental designs. I follow Cook and Campbell (1979:296) that suggest to consider "'treatments', such as attending a particular training program, even where the program was a permanent institution and where the researcher did not manipulate anything," provided she is able to identify what it is about the treatment that presumably caused group differences on the phenomenon of interest.
} 
influences) and the other has not. The effect of transnational influences is defined as the difference between the attitudes of these two groups, while including explicit controls for relevant alternative influences.

Given that comprehensive and reliable information about the larger population of Moroccan state officials is unavailable, I opted for a theoretically controlled cluster sampling and asked all the officials working in particular departments of certain ministries (that is, the clusters) to participate. In view of the study's focus on the potential democratization effects of networks, the departments were selected on the basis of their participation/non-participation in a network. Multilevel analysis to estimate cluster effects shows that the between-departments component of variance is close to zero (3.303e-11). Accounting for this component of variance will thus not much affect inferences. ${ }^{5}$

Specifically, I centered on the EU Twinning program, a highly institutionalized type of inter-administrative cooperation that builds on the secondment of European experts for a maximum of two years. ${ }^{6}$ A Twinning project provides for day-to-day contact in seminars, workshops, training sessions, and meetings on the basis of normal work relations between Moroccan and European officials. All officials working in a benefiting department belong, in principle, to the target group of such a project. That is, the appointment as a participant is not based on specific individual characteristics (selective recruitment). Drawing on this selection of benefiting departments, I identified additional, thematically similar departments that were not subject to any EU Twinning project. To give an example, the project "Support for the Strengthening of the Competition Authorities" (MA06/AA/FI08) benefits the Department for Competition and Prices of the Moroccan Ministry for Economic and General Affairs. A suitable comparable department is, for instance, the Department for Treasury and External Finances of the Ministry for Economy and External Finances. Officials working in these non-benefiting departments constitute the comparison group for the treatment "network." A quarter of the officials in this comparison group participated in policy programs other than the Twinning program, for which I control in the regression analyses. Moreover, two individual state officials were called in a Twinning project, although their department was not involved as a whole. These officials are treated as non-participants in the main analysis and excluded when examining robustness, without affecting the results. ${ }^{7}$ Overall, there is no bias with regard to the ministries selected, although officials employed by the Ministry of Economy and Exterior Finances, the Ministry of Agriculture, and the Ministry of Energy are overrepresented as they hosted EU Twinning projects (see Appendix 1). In brief, I can exclude the possibility that only those state officials who are particularly open-minded, or alternatively, loyal to the regime, agreed to fill in the questionnaire.

In addition, I assess whether the two groups are similar in relevant characteristics and control for the possibility that exposure to transnational influences is driven by

\footnotetext{
${ }^{5}$ I do employ robust standard errors that control for intra-group correlations.

${ }^{6}$ For more information on the EU's Twinning program, see http://ec. europa.eu/europeaid/where/neighbourhood/overview/twinning_en.htm.

7 The two extra-departmental Twinning participants are employed in the Ministry of Foreign Commerce, classified as politicized. If they are removed from the analysis, the results remain stable (available upon request).
}

confounding variables such as age and level of education (self-selection). Welch t-tests on the individual imputed data sets show that there is no statistically significant effect for exposure to foreign media or study abroad depending on the ministry/department in which the state official works. ${ }^{8}$ As to the network participants, it could be reasoned that in certain policy fields, notably those that are less politicized, ${ }^{9}$ state officials are more perceptive of democratic governance than in others. Regression analyses including politicization as predictor do not corroborate the expectation that state officials in less politicized fields are more democratically minded (see Table S2 in the Online Appendix). Moreover, descriptive statistics of the sample distribution show no systematic pattern in the distribution of conventional socio-demographic characteristics across the three types of transnational influence (see Table S1). Overall, the sample appears to be large and diverse enough to draw meaningful conclusions. Both senior officials responsible for the management of the relevant administrative unit ("directorate") and junior and middle level officials ("administrative staff") are represented in a similar manner. The same holds true for education level (graduate or postgraduate studies), subject (law/economics, natural sciences, and public administration), language skills, and gender. If I control for a potential selection bias by repeating the regression analyses with data matched on those variables that assumedly motivate exposure, the results remain robust. ${ }^{10}$ It appears that both groups do not differ considerably with regard to third, possibly confounding features on average; the difference in attitudes can be reliably associated with the treatment effect.

\section{Operationalization of the Treatment Variables}

The variable "Foreign Media" applies to print media and television channels originated in established democracies. Respondents were asked to indicate which newspapers/ magazines and television channels they use for political information, in which languages, and how often they do so. The media products used come predominantly from Europe, in particular France and the United Kingdomabout $97 \%$ of foreign print media and $94 \%$ of foreign TV channels. Media penetration is treated as dichotomous with 1 representing regular use. The second transnational variable, "International Education," refers to the international experiences of officials, operationalized as a stay abroad in a democratic country of at least 6 months for educational or professional reasons. This variable is coded as a binary variable with 1 for residence in an established democracy. In total, 63 state officials studied abroad, 48 of them stayed in Europe, nine of them in the United States/Canada, and six in both world regions. There are no significant differences in attitude toward democratic governance between officials who had spent a considerable period of time in Europe and those who had been in North America or in both host destinations,

\footnotetext{
${ }^{8}$ For the first imputed data set, ministry: $t_{\text {media }}(44.56)=-1.59, p=.12$; $t_{\text {abroad }}(135.167)=-0.24, \quad p=.81 \|$ department: $t_{\text {media }}(48.33)=-3.65$, $p=.52 ; t_{\text {abroad }}(129.48)=-0.11, p=.91$.

${ }^{9}$ Politicization here refers to the importance of the policy issues for the integrity of the state and maintenance of political power by the ruling elite (Zimmerman 1973:1204).

${ }^{10}$ I replicated the regression analyses by employing genetic one-to-one matching with replacement (Diamond and Sekhon 2013), see Table S4 in the Online Appendix.
} 
as shown by a non-significant analysis of variance (ANOVA) $F$-test $(F(3)=0.025, p=.88$, for combined scale). Officials who had spent a considerable time in "the West" do not consult Western media substantially more often, as supported by a non-significant Pearson's chi-squared test $\left(\chi^{2}(1,138)=0.39, p=.53\right)$. Finally, the third variable, participation in "Transgovernmental Networks" is entered as a binary variable with value 1 if the official had participated in a EU Twinning project. $55.3 \%$ of the respondents were involved in a Twinning network.

\section{Operationalization of the Dependent Variable: Democratic Socialization}

The dependent variable is democratic socialization, understood as change in attitude toward democratic governance. Democratic governance involves the idea that democratic principles are applicable to every situation in which collectively binding decisions are taken (Dahl 1971:12; Beetham 1999:4-5). These principles can thus be translated into administrative rules and practices at the level of subunits of state administration, even within a nondemocratic polity. Unlike good governance, democratic governance is not limited to effectiveness and efficiency but includes the legitimization of governance through democratic rules and practices. Enhancing the legitimacy of governance requires more than simply delivering more, better, or faster services. Instead, the conditions for increasing legitimacy include undertaking initiatives focused on making public-sector activities more transparent, accountable, interactive, and accessible to citizens. Attitudes toward democratic governance thus capture state officials' understandings of the extent to which and the way in which public affairs shall be managed in respect to the citizens' right to govern themselves.

Since this study could not build on existing surveys, it required the creation of an original scale measuring the degree of agreement with democratic governance. In previous work, I apply an understanding of democratic governance as a multidimensional construct encompassing three core dimensions, participation, transparency, and accountability (for example, Freyburg et al. 2011). For the purpose of this study, however, my interest was to develop a concise, construct-valid measure with acceptable properties of administrative decision making, suitable to conduct initial explorations in this area. Conceptual work on public administration (reform) and the linkage between (good) governance and development (see Baker 2002; Hydén, Court, and Mease 2004) inspired the formulation of statement items pertaining to various aspects of democratic administrative governance.

The questionnaire contains statements on both democratic (positively oriented items) and nondemocratic governance features (negatively oriented items). The incorporation of both statement types allows accounting for the general tendency to provide affirmative answers, regardless of the content ("acquiescence effect"). I analyze the association between transnational influence and agreement with democratic governance for the two statement types separately and by using a scale combining them. A combined scale is in line with the theoretical idea that a true democrat is one who supports items of regular democratic governance and rejects their logical

Table 1. Measurement of Attitude Toward Democratic Governance

Exact Wording of the Statement Item

\begin{tabular}{|c|c|c|c|c|c|c|c|}
\hline \multicolumn{8}{|c|}{$\begin{array}{l}\text { Question: "There are different opinions as to what it takes to be a 'good' civil } \\
\text { servant. To what extent do you personally agree or disagree that a civil } \\
\text { servant should have the following qualities?" }\end{array}$} \\
\hline 1 & $\begin{array}{l}\text { "A civil servant should provide citizens with the possibility of advancing their } \\
\text { views as an input for governmental decision making" }\end{array}$ & 0.40 & & 0.39 & 4.51 & 0.71 & $\overline{144}$ \\
\hline 2 & $\begin{array}{l}\text { "A civil servant should take into account the views and concerns } \\
\text { of affected citizens before making decisions" }\end{array}$ & 0.50 & & 0.42 & 4.63 & 0.71 & 145 \\
\hline 3 & $\begin{array}{l}\text { "A civil servant should ensure that the citizens' views and concerns } \\
\text { have an influence on shaping policies" }\end{array}$ & 0.48 & & 0.52 & 4.47 & 0.72 & 142 \\
\hline 4 & "A civil servant should make information available to anyone requesting it" & 0.05 & & 0.10 & 4.62 & 0.81 & 146 \\
\hline 5 & $\begin{array}{l}\text { "A civil servant should work in a manner that is transparent and } \\
\text { comprehensible for the general public" }\end{array}$ & 0.30 & & 0.34 & 4.85 & 0.41 & 147 \\
\hline 6 & "A civil servant should offer updated information on governmental policy" & 0.40 & & 0.41 & 4.42 & 0.82 & 139 \\
\hline $\mathrm{n} 1$ & $\begin{array}{l}\text { "A civil servant should always seek to bring the public into accordance } \\
\text { with the government policy" }\end{array}$ & & 0.10 & 0.08 & 1.96 & 1.19 & 138 \\
\hline $\mathrm{n} 2$ & $\begin{array}{l}\text { "A civil servant should assure that all information held by public authority } \\
\text { remains in the hands of the government only" }\end{array}$ & & 0.24 & 0.09 & 3.81 & 1.19 & 134 \\
\hline \multicolumn{8}{|c|}{$\begin{array}{l}\text { Question: "There are different understandings of what determines the appropriateness } \\
\text { and procedural correctness of bureaucratic acts in public administration. To } \\
\text { what extent do you personally agree that the following items serve this function?" }\end{array}$} \\
\hline 7 & $\begin{array}{l}\text { "Monitoring by independent state institutions ensures the appropriateness and } \\
\text { procedural correctness of bureaucratic acts" }\end{array}$ & 0.34 & & 0.20 & 4.24 & 1.03 & 136 \\
\hline 8 & $\begin{array}{l}\text { "Possibilities for the general public and its associations to request scrutiny of the } \\
\text { decision-making process and review of policies ensures the appropriateness and } \\
\text { procedural correctness of bureaucratic acts" }\end{array}$ & 0.20 & & 0.13 & 4.28 & 0.94 & 135 \\
\hline n3 & "Instructions of and approval by the higher authority" & & 0.18 & 0.17 & 2.93 & 1.24 & 134 \\
\hline \multicolumn{2}{|c|}{ Scale reliability $\alpha$} & .62 & .30 & .53 & & & \\
\hline
\end{tabular}

(Note. Entries in columns 1-3 are the corrected item-total correlations, that is, the correlation of the respective item with the scale total excluding that item. Items are measured on a 5 -point Likert-type scale $(1=$ strongly disagree; $5=$ strongly agree $)$, with reversed values for the negatively oriented items $(\mathrm{n} 1-\mathrm{n} 3))$. 
opposites. A separate analysis, in turn, acknowledges that agreement with positively and negatively oriented items follows different logics. Agreeing with positively framed democratic items is assumed to be "easier" and more justifiable for state officials employed in an authoritarian regime that declares itself a "modern" state than explicitly rejecting their logical opposites that refer to the still prevailing authoritarian culture. Table 1 displays the exact wording of the items plus the results of a basic reliability analysis for the three constructed scales (columns 1 to 3 ).

Each of the items is measured on a 5-point Likert-type scale $(1=$ strongly disagree; $5=$ strongly agree $)$ with reversed values for the negatively oriented items. The items' values are summed to create an index ranging from 8 to 40 for the positively oriented items, from 3 to 15 for the negatively oriented items, and, correspondingly, from 11 to 55 for the combined measure, with higher total scores reflecting a greater agreement with democratic governance. The internal reliability of the created scale, indicated by Cronbach's $\alpha$ in Table 1, is acceptable given the exploratory character of the study, its objective (attitudes), the skewness of the item distribution, and the small number of observations (John and Benet-Martínez 2000:346). I cross-checked the results' validity by running the regression analyses on a scale without item 4 that correlates low with the overall score of the scale; Cronbach's $\alpha$ increases to .66, but the estimation results are similar, as is also corroborated by non-significant ANOVA F-tests comparing the two full regression models $\left(F_{\text {media }}(1,137)=0.07, \quad p=.79, \quad F_{\text {abroad }}(1,137)=\right.$ $\left.0.32, p=.57, F_{\text {networks }}(1,137)=1.97, p=.16\right) .^{11}$ I believe that the scale reflects a construct-valid measure of attitudes toward democratic governance and keep item 4 for its theoretical importance.

Despite the precautions taken in questionnaire design and survey setting, the existence of preference falsification cannot be completely ruled out. For two principal reasons, this hardly signifies a problem for this study. First, I am not primarily interested in identifying the true understanding of appropriate governance among Moroccan state officials. Instead, I am concerned with estimating the differences in agreement with democratic governance between state officials who have been exposed to transnational influences and those who have not. It can essentially be assumed that there is no systematic bias of response tendencies. Second, response behavior that is conventionally problematized as social desirability bias is actually part of my understanding of socialization as encompassing both "Type I" socialization (cognitive attitude change) and "Type II" socialization (affective attitude change). Type I socialization involves "role-playing" (Checkel 2005:810-1). As a consequence of their professional exchange with bureaucrats from established democracies, Moroccan officials might have learned what kind of governance is seen as appropriate by their Western counterparts and therefore tend to agree with statements describing democratic governance, irrespective of whether they believe in its normative validity or not. In other words, socially desirable response behavior requires prior cognitive learning processes and, as such, it can be seen as a feature of democratic socialization (Risse, Ropp, and Sikkink 2013:284-5).

The distribution of the outcome variable is shown by asymmetric beanplots (Kampstra 2008), one per type of

11 The complete results of the analysis of variance and the regression analysis using the modified scale are available upon request. transnational influence, as displayed in Figure 1. "Transnational influences" is operationalized with 1 if the individual official is exposed to at least one of the three types of cross-national activities. The beanplots show the arithmetic mean per subgroup (black line), the arithmetic mean averaged over all groups (dashed line), and an approximate distribution per subgroup using Kernel distribution estimates with cuts at the respective minimum and maximum values (asymmetric polygon shape). The latter element provides a histogram-like visualization of the concentration of points and normality of the distribution. It is filled black for the values of the respective comparison group and gray for those of the treatment group. The higher the value the more the respondent is in favor of the relevant item (that is, the more "democratic").

A cursory glance at the distribution of agreement with the democratic governance items suggests that transnational influences (left-hand plot) can have a positive effect, as demonstrated by higher adjacent values, a higher mean line, and a more elongated shape for the treatment group (gray). Figure 1 also points, as expected, to variance in the effect between the different types of transnational influences. The main difference is that, overall, the more diffuse types of cross-national activities -international education and foreign media-tend to have a negative effect on the state officials' attitudes toward democratic governance, as indicated by, among others, a lower mean line and lower adjacent values for the treatment groups. In contrast, participation in policy networks seems to have positively influenced the attitudes of the concerned state official; the majority of data points accumulated in the upper range, and the tail is considerably shorter.

It is generally noticeable that all groups show a remarkably high degree of agreement with the statements, given that the respondents are state officials employed by an authoritarian regime reluctant to any noteworthy political liberalization; the middle values are clearly located in the realm of a positive attitude toward democratic governance. However, it also appears as if the state officials' understanding of some features is still partially rooted in an authoritarian culture of rule-making. This interpretation is supported by the overall high rate of non-response to the three negatively oriented items. Strikingly, onethird opted for the neutral position and about $10 \%$ refused to state its preference. How do state officials employed in a nondemocratic environment come to appreciate democratic elements of governance? And, are the visually detected differences in the attitudes of officials exposed to different types of transnational influences statistically significant?

\section{Empirical Results}

\section{Quantitative Analysis of Survey Data}

To answer this question, I rely on both quantitative and qualitative approaches to data analysis. I first conduct a series of multiple least square regression analyses to estimate the association between transnational influences and attitudes toward democratic governance. As dependent variable, I first enter a scale aggregating all statement items, and then a scale limited to the positively oriented items and the negatively oriented items, respectively. For each set of estimations, I first estimate the independent effect of each transnational activity. This step also allows Hypothesis 4 to be tested on the difference in socialization between 


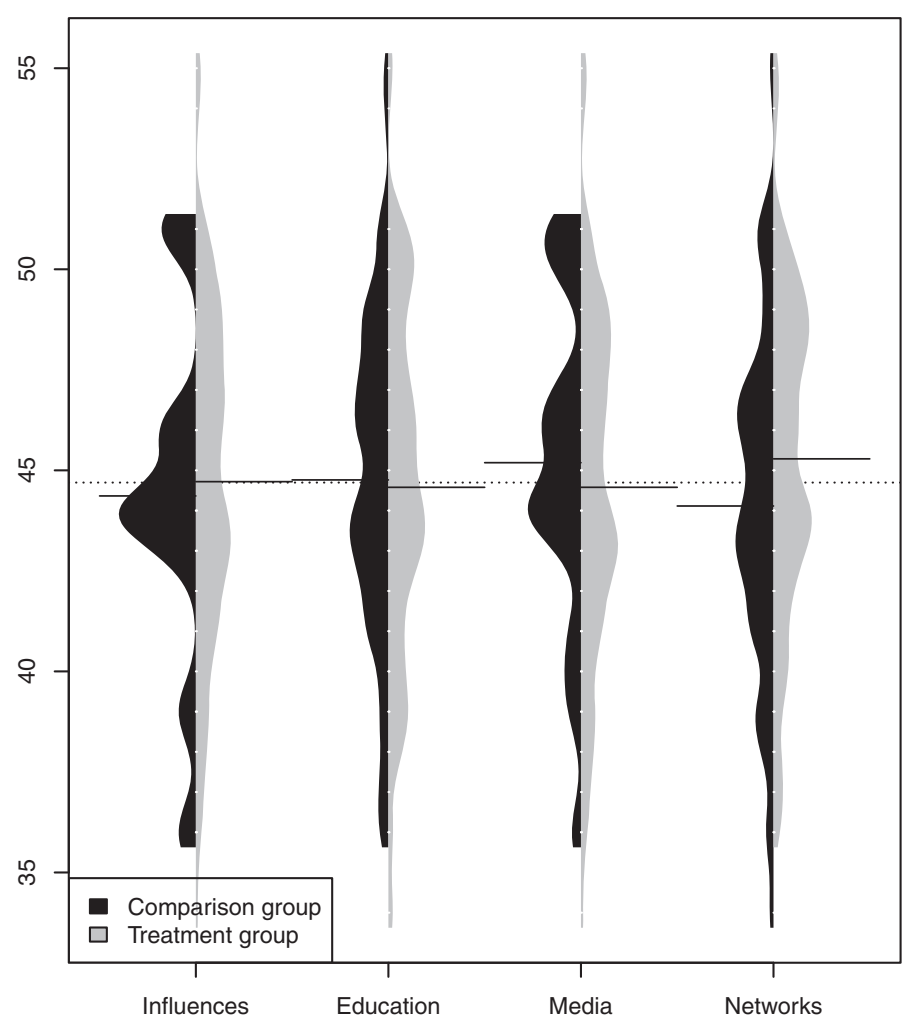

FIG 1. Moroccan State Officials' Attitudes toward Democratic Governance.

(Notes. Values range from 11 ("nondemocratic") to 55 ("democratic"); $N=150$, cases with missing values excluded listwise.)

the three types and the expected stronger effect of networks. I then add interaction terms for the relevant pairs of influences to test Hypothesis 5 on the supporting effect of prior experiences.

In each step, the respective full model includes all three treatment variables and a number of control variables related to relevant characteristics of the individual state officials, namely their level of education (with graduate $=0$ and postgraduate studies $=1)$, the subject of study (Law/Economics, Public Administration, or Natural Sciences, introduced as dummy variables with the latter as baseline), their knowledge of English (with 1 for "good" knowledge, that is, scores $\geq 3$ on scale ranging from 5 ("excellent") to 0 ("no knowledge")), ${ }^{12}$ their position within the state administration (with directorate $=1$ ), age, and gender (with female $=1$ ). I also control for participation in policy programs other than the Twinning program and the degree of politicization of the department. In total, $19.3 \%$ of the Twinning non-participants were involved in an alternative project that was set up by the European Union, its member states, the United Nations Development Program (UNDP), the United States Agency for International Development Aid (USAID), the World Bank, or the Japan International Cooperation Agency (JICA). A department's degree of politicization is determined by the extent to which it touches upon internally sensitive issues such as corruption, patronage, and the mixing of private business with governmental responsibilities. Interviews with (non-) governmental representatives from Morocco, Brussels, and EU member states helped to classify the selected departments, marked with an asterisk in Appendix 1.

${ }^{12}$ I refrain from including French skills as only two officials rated them as less-than-good.
I run the regression analyses after multiple imputation of the missing values under the assumption of missing at random, that is, missingness depends on other information in the data set (King, Honacker, Joseph, and Scheve 2001:50-51). I replace each missing value by a set of $m=5$ plausible values drawn from their predictive distribution. I then conduct the analyses separately for all five imputed data sets and combine them using the rules described by King et al. (2001). The imputation model includes all the variables from the full analysis model plus a number of additional statement items that help predict the missing values. ${ }^{13}$ The results remain robust if regression is run on the pre-imputed complete-case data set and on each imputed data set, as is also corroborated by non-significant ANOVA $F$-tests comparing the respective regression models (see Appendix 2). ${ }^{14}$

The regression results support the democratizing potential of transnational influences; however, as expected, not all types yield democratic socialization to the same extent. Figure 2 displays the point estimates and $95 \%$ confidence intervals of the full regression models when using separate scales for the positively oriented items and the negatively oriented items (right-hand panel) and a scale combining the two statement types (left-hand panel). ${ }^{15}$ Both panels suggest that, contrary to conventional wisdom, state officials who use foreign

\footnotetext{
13 The exact wording of the additional statement items is available upon request.

${ }^{14}$ For the regression results on the pre-imputed complete-case data set, see Table S6; the results on each imputed data set are available upon request.

${ }^{15}$ I omit the estimate and standard error of the constant because it is not substantial meaningful in this case: the constant is the predicted value for a state official, who has unlikely if not impossible characteristics, such as age zero.
} 

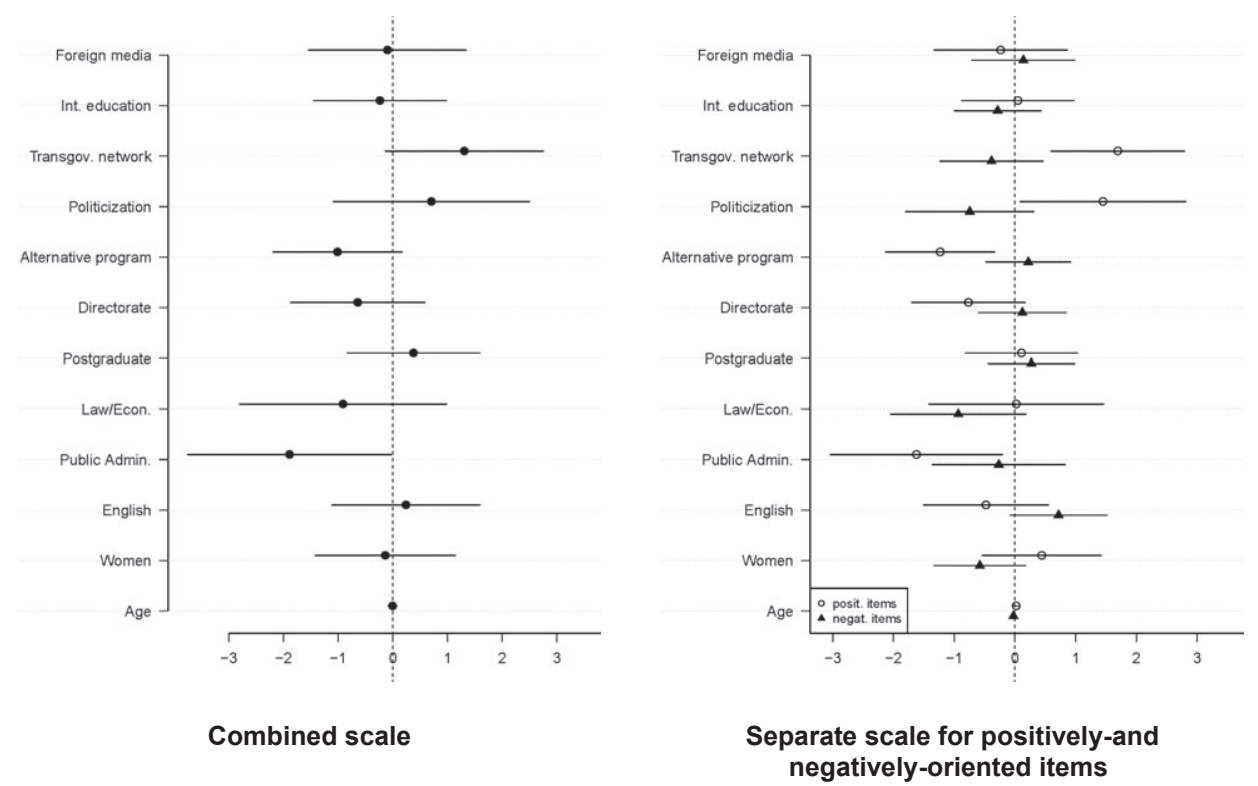

FIg 2. Transnational Activities and State Officials' Attitudes toward Democratic Governance (Notes. Coefficients of multiple least square regression analyses are unstandardized with a $90 \%$ confidence interval (horizontal lines), $N=150$, missing values multiply imputed.)

media or have stayed abroad in an established democracy for educational reasons are not more supportive of democratic governance than their colleagues without similar experiences. In both cases, the coefficient lines cross the reference line: the two conventional treatment variables are not significantly different from the null hypothesis. Moreover, in some models, the coefficient is, overall, even slightly (but not significantly) negative, which points to an anti-democratic effect. In contrast, as expected, participation in transgovernmental policy networks appears to have an attitude-shaping effect: The coefficient is positive, if measured with a scale limited to the positively oriented statement items $(B=1.69, t(138)=2.54, p=.01)$ or a scale combining the two statement types $(B=1.31, t$ $(137)=1.49, p=.14)$. Yet, the right-hand panel suggests that while participation in transgovernmental networks can positively and statistically significantly influence the attitudes of state officials toward the democratic features of governance, the influence seems to be not strong enough so to also significantly shape their attitudes toward the nondemocratic features. It appears as if some Moroccan state officials are caught between two logics of appropriateness: the traditional, authoritarian conception of bureaucratic decision making and the liberal-democratic alternative. Apparently, these officials do not know what definition of appropriateness to follow when confronted with conflicting understandings. Overall, on the basis of this study, Hypotheses 1 and 2 on the independent effect of international education and foreign media cannot be confirmed. Instead, the estimation results support Hypothesis 3 on the transformative potential of transgovernmental networks. In this vein, the regression results corroborate Hypothesis 4 on variance in effect between different types of transnational interchange. As hypothesized, exposure is more likely to shape the attitudes if it provides contact with democratic governance in a structured and targeted interpersonal manner.

To what extent is the socialization potential of transgovernmental networks boosted by the influence of other transnational influences? In order to test the conditional effect (Hypothesis 5), I introduce cross-product terms of networks with the two alternative contact variables in the full regression model. The regression results reveal that both interaction terms "transgovernmental network $\mathrm{x}$ foreign media" $(B=0.70, t(136)=-0.39, p=.70$, for the combined scale) and "transgovernmental network $\mathrm{x}$ international education" $(B=-0.80, t(136)=-0.56, p=.58)$ are not statistically significantly associated with agreement with democratic governance (see Table S3 for complete results). It thus appears that there is no such repetition effect as postulated in Hypothesis 5. However, this question warrants further research as the intensity and regularity of exposure or the time interval between exposures to different transnational influences, among others, might determine whether there is an enforcing interaction effect.

\section{Qualitative Analysis of Interviews and Answers to Open Survey} Question

Interviews with European officials in 2007 and 2008 and the written answers to an open survey question by the Moroccan officials are used to evaluate the plausibility of democratic socialization in transgovernmental networks. I interviewed in total 15 officials from the European Commission and EU member states that were selected on the basis of their responsibilities. In addition, concluding the questionnaire, all Moroccan officials were asked whether they "have any further remarks in regards to the reality of bureaucratic structures in Morocco and [... their] daily work." Overall, 42 officials shared their comments; half of them had participated in a transgovernmental network. Since it is difficult to assess the uncertainty involved in drawing inferences from this non-representative sample, this qualitative material is used only to illustrate the plausibility of the argument.

The interviews corroborate the finding that state officials can become acquainted with democratic governance through participation in transgovernmental networks. According to one interviewee, Twinning projects are 
"administrative reality" (EU7) ${ }^{16}$ in that cooperation happens within state administration: European experts settle down in the benefitting ministries for a few years in order to work jointly on solutions to policy problems on a daily basis. The projects, another European official (EU2) emphasized, offer "activities trying to help [... the state officials of the partner country to] understand better what they have to do in order to fulfill the agreements and how to progress. [... They] have to change their minds about how to organize things." In a similar vein, one of the project leaders (EU12) reasoned that the participating Moroccan officials "get the feeling that it could work differently and appraise that the Twinning project asks them to take up the initiative and to think actively. [...] They regret that they cannot work like this outside the program."

This observation corresponds to the Moroccan officials' self-reports: The majority of the respondents complained about the hierarchical top-down structure of state administration and the lack of performance-based career advancement; two-thirds of them were network participants. As one 34-year-old participant in an environmental network stated, "The Moroccan government is deeply marked by corruption, demotivation, lack of protection of the rights of employees against the hierarchical abuse of power, disorganization, irresponsibility, and other related malaise" (MA7). ${ }^{17}$ This general discontent with the functioning of the administration was echoed in personal communication with officials after they had filled in the questionnaire. When asked how satisfied they are with their jobs, many reported that they appreciated being called on to reflect on the policy problem at stake and to produce possible solutions themselves. They would welcome having more responsibility and the possibility of working closer to the concerns of the population.

As to democratic governance precisely, most officials who answered the concluding question complained about the lack of transparency, in particular in terms of administrative procedures of decision making and the exchange of information between different administrative branches, but also to citizens. Many explicitly mentioned the lack of mechanisms holding officials accountable. In the words of a 52-year-old official working in the Secretary of Water and Environment, "Administrative work is not sufficiently controlled in terms of its efficiency and regulatory correctness. [...] Appeals against the decision of the administration are rarely brought before the courts" (MA4). A number of respondents noted that "the mentality of the officials" (MA14) needs to change. A 46-year-old participant in the EU-financed program on free commercial trade specified that due to the "non-reactivity between administration and citizens [...] administration is perceived by the people as power and not as public service to meet their needs." His 35-year-old colleague concurred by saying that "the attitudes of the state officials toward citizens needs to change" (MA13). Officials "close to the citizens, ambitious, conscious, and take on responsibility" are needed (MA10).

\section{Conclusion}

"Change through rapprochement" is a slogan used to promote democratization through a policy that gradually

\footnotetext{
16 Table S5 gives more information about the interviews. In order to guarantee my interview partners' anonymity, I use interview codes; EU stands for European, MA for Moroccan officials.

17 All citations are translated from French and Arabic by the author.
}

relies upon the magnetic force of political liberties and economic opportunities. This policy of proximity is based on the assumption that transnational interchange creates channels of diffusion, changing the attitudes if not the behavior of domestic agents in authoritarian regimes and turning them into democratically minded opponents. Research on the "contact hypothesis" in social psychology teaches us that socialization effects depend on the quality of contact: the more structured and direct exposure occurs, the more likely it is to shape attitudes. Insights from sociology that fed the "practice turn" in International Relations point to the importance of experiential learning by doing. Drawing on this, the present study set out with two main suppositions: first, if the theoretical assumptions on attitude change through exposure to transnational influences are correct, there should be a relationship between exposure to democratic governance and attitudes toward it; and second, this relationship should be stronger if exposure happens in a structured and targeted interpersonal setting that guarantees direct contact and allows for practicing.

Multiple least square estimations on original data from a survey among 150 Moroccan state officials have shown that not all types of transnational interchange yield processes of democratic socialization. Contrary to conventional wisdom, I find no significant effect of exposure to foreign media or from international education on attitudes toward democratic governance. This finding casts doubt on the effectiveness of study abroad programs and foreign media broadcasting as tools for democracy transfer although, on the basis of the present analysis, it cannot be concluded that international education or foreign media per se are unlikely to yield democratic socialization; further studies are needed to control more explicitly for factors such as the quality of contact with democratic governance. Moreover, foreign media users and international students tend to be a self-selected group. It is thinkable that only those who have either close links to the political elite and/or are perceived as regime supporters can afford to study abroad in order to strengthen their loyalty and avoid undesired effects such as those studied here. Foreign media, in turn, can be assumed to be more attractive for state officials that are generally open toward external influences and interested in developments taking place in democratic foreign countries. While this question deserves additional research, descriptive statistics allow for the tentative conclusion that if self-selection applies, it seems to have no major influence (see Figure 1). It appears that the treatment group "international education" shows no particularly negative attitude toward democratic governance, as should be expected if selfselection was true (or the effect of studying abroad must be extremely strong). Likewise, the attitudes of the officials using foreign media do not appear to be considerably more positive.

Instead, my analyses suggest that a previously overlooked type of transnational exchange-transgovernmental networks - can positively influence the attitudes of state officials. Officials who have participated in the activities of policy reform programs undertaken by established democracies show a higher agreement with democratic administrative governance than their non-participating colleagues. The results advance the conclusion that international factors can yield processes of transnational socialization, but only if they create a site for interpersonal and structured exchange bringing together people from democracies and nondemocracies. Networks provide 
the opportunity to become acquainted with democratic principles and practices at the elbow of a master. By applying abstract democratic principles to everyday practices, they can be seen as a kind of apprenticeship in democratic governance. Yet, it appears as if the influence is not strong enough as to make participants to also reject nondemocratic features of administrative governance. I find no empirical evidence for an increased likelihood of a positive attitude-shaping effect due to prior exposure to democratic governance either, such as a study stay in a democracy.

This study of Moroccan state officials' attitudes and whether they are shaped by transnational influences represents one step toward a better understanding of the democratization potential of transnational influences. Although the results presented cannot provide a comprehensive explanation, they suggest transgovernmental net- works be a promising venue for democratic socialization. Future research is encouraged to explore not only which types of networks are more effective, under what conditions, and why but also what socio-structural factors facilitate attitude change. Here, the literature on Social Identity Theory, as originally put forward by Tajfel and Turner (1979), and its spin-off, Self-Categorization Theory (Turner 1985), seem to be a particularly promising point of departure. Another challenge for future research is to specify the conditions for any potential behavioral application of democratic modes in daily administrative practices and its effects in terms of democratization proper. It remains to be seen whether (and if so, how and under what conditions) such democratic administrative governance will ultimately spill over into the general polity by unfolding dynamics that promote democratization rather than stabilization of the entire political system.

\section{Appendix:}

ApPENDIX 1. Distribution of Original Sample before Multiple Imputation

\begin{tabular}{|c|c|c|c|c|c|c|c|c|c|}
\hline & \multicolumn{3}{|c|}{ Foreign Media } & \multicolumn{3}{|c|}{ Intern. Education } & \multicolumn{3}{|c|}{ Transgov. Networks } \\
\hline & No & Yes & $N$ & No & Yes & $N$ & No & Yes & $N$ \\
\hline$N$ & 29 & 112 & 141 & 84 & 63 & 147 & 67 & 83 & 150 \\
\hline \multicolumn{10}{|l|}{ Ministries } \\
\hline Agriculture, Rural Development, and Fishing* & 5 & 26 & 31 & 14 & 19 & 33 & 9 & 24 & 33 \\
\hline Economic and General Affairs* & 2 & 7 & 9 & 6 & 4 & 10 & 0 & 10 & 10 \\
\hline Economy and Exterior Finances* & 8 & 19 & 27 & 21 & 8 & 29 & 12 & 17 & 29 \\
\hline Energy, Mining, Environment, and Water & 3 & 36 & 39 & 22 & 16 & 38 & 9 & 32 & 41 \\
\hline Equipment and Transport* & 1 & 5 & 6 & 3 & 3 & 6 & 6 & 0 & 6 \\
\hline Foreign Commerce* & 0 & 2 & 2 & 1 & 1 & 2 & 2 & 0 & 2 \\
\hline Health & 3 & 8 & 11 & 6 & 6 & 12 & 12 & 0 & 12 \\
\hline Housing, Urban Development, and Planning & 1 & 4 & 5 & 4 & 1 & 5 & 5 & 0 & 5 \\
\hline Industry, Trade, and New Technologies* & 1 & 3 & 4 & 3 & 1 & 4 & 4 & 0 & 4 \\
\hline National Education, Higher Education, and Scientific Research & 5 & 2 & 7 & 4 & 4 & 8 & 8 & 0 & 8 \\
\hline \multicolumn{10}{|l|}{ State Officials } \\
\hline \multicolumn{10}{|l|}{ Position } \\
\hline Administrative Staff $(0)$ & 20 & 58 & 78 & 53 & 30 & 83 & 39 & 45 & 84 \\
\hline Directorate (1) & 9 & 54 & 63 & 31 & 33 & 64 & 28 & 38 & 66 \\
\hline \multicolumn{10}{|l|}{ Education Level } \\
\hline University Diploma (0) & 13 & 38 & 51 & 37 & 16 & 53 & 26 & 28 & 54 \\
\hline Postgraduate (1) & 15 & 74 & 89 & 46 & 47 & 93 & 41 & 54 & 95 \\
\hline \multicolumn{10}{|l|}{ Subject of Study } \\
\hline Law/Economics & 13 & 42 & 55 & 41 & 17 & 58 & 29 & 29 & 58 \\
\hline Natural Sciences & 10 & 60 & 70 & 33 & 39 & 72 & 29 & 46 & 75 \\
\hline Public Administration & 4 & 9 & 13 & 9 & 5 & 14 & 9 & 5 & 14 \\
\hline \multicolumn{10}{|l|}{ Languages } \\
\hline French & 29 & 111 & 140 & 83 & 62 & 145 & 67 & 81 & 148 \\
\hline English & 20 & 89 & 109 & 63 & 51 & 114 & 51 & 64 & 115 \\
\hline \multicolumn{10}{|l|}{ Gender } \\
\hline Women & 14 & 35 & 49 & 30 & 21 & 51 & 31 & 21 & 52 \\
\hline
\end{tabular}

(Notes. Frequencies in numbers; Foreign language competences range from excellent knowledge (5) to no knowledge (0); scores between three and five are valued as good knowledge and indicated in the table; the asterisk $(*)$ marks politicized policy fields.) 
ApPENDIX 2. Comparison of Regression Models Before and After Multiple Imputation

\begin{tabular}{|c|c|c|c|}
\hline & Model $C$ & Model P & Model $N$ \\
\hline \multicolumn{4}{|c|}{ Treatment Variables } \\
\hline $\begin{array}{l}\text { Foreign } \\
\text { Media }\end{array}$ & $F(1,89)=0.45$ & $F(1,96)=0.66$ & $F(1,99)=0.01$ \\
\hline $\begin{array}{l}\text { Internat. } \\
\text { Education }\end{array}$ & $F(1,89)=0.04$ & $F(1,96)=0.52$ & $F(1,99)=0.08$ \\
\hline $\begin{array}{l}\text { Transgov. } \\
\text { Network }\end{array}$ & $F(1,89)=3.44$ & $F(1,96)=3.15$ & $F(1,99)=0.51$ \\
\hline \multicolumn{4}{|l|}{ Control Variables } \\
\hline $\begin{array}{l}\text { Alternative } \\
\text { Program }\end{array}$ & $F(1,89)=0.11$ & $F(1,96)=2.45$ & $F(1,99)=2.08$ \\
\hline Politicization & $F(1,89)=4.28^{*}$ & $F(1,96)=5.00^{*}$ & $F(1,99)=0.20$ \\
\hline Directorate & $F(1,89)=1.80$ & $F(1,96)=2.01$ & $F(1,99)=0.23$ \\
\hline Postgraduate & $F(1,89)=0.34$ & $F(1,96)=0.23$ & $F(1,99)=0.85$ \\
\hline \multicolumn{4}{|c|}{ Study Subject (re. Natural Sciences) } \\
\hline $\begin{array}{l}\text { Law/ } \\
\text { Economics }\end{array}$ & $F(1,89)=0.13$ & $F(1,96)=3.61$ & $F(1,99)=1.36$ \\
\hline $\begin{array}{l}\text { Public } \\
\text { Admin. }\end{array}$ & $F(1,89)=4.56^{*}$ & $F(1,96)=3.78$ & $F(1,99)=1.51$ \\
\hline English & $F(1,89)=0.04$ & $F(1,96)=0.06$ & $F(1,99)=1.04$ \\
\hline Women & $F(1,89)=0.03$ & $F(1,96)=0.01$ & $F(1,99)=1.03$ \\
\hline Age & $F(1,89)=2.51$ & $F(1,96)=1.92$ & $F(1,99)=0.02$ \\
\hline
\end{tabular}

(Notes. Analysis of variance is performed to compare the full models $C, P$, and $N$ in Table S2 (multiple-imputation-based data set) and Table S6 (completecase data set); in Model $C$, the dependent variable is measured using scale combining positively and negatively oriented items, Model $P$ is limited to the former and Model $N$ to the latter; ${ }^{*} p \leq .05, * * p \leq .01, * * * p \leq .000$.)

\section{References}

Al-Arkoubi, Khadja, and Willy McCourt (2004) The Politics of HRM: Waiting for Godot in the Moroccan Civil Service. International Journal of Human Resource Management 15(6): 978-995.

Allport, Gordon (1954) The Nature of Prejudice. Cambridge: AddisonWesley.

Atrinson, Carol (2010) Does Soft Power Matter? A Comparative Analysis of Student Exchange Programs 1980-2006. Foreign Policy Analysis 6(1): 1-22.

BAKER, RANDAll (ED.) (2002) Transitions from Authoritarianism. The Role of the Bureaucracy. London: Praeger.

Beetham, David (1999) Democracy and Human Rights. Cambridge: Polity Press.

Beyers, Jan (2005) Multiple Embeddedness and Socialization in Europe: The Case of Council Officials. International Organization 59(4): 899936.

Beyers, Jan (2010) Conceptual and Methodological Challenges in the Study of European Socialization. Journal of European Public Policy 17 (6): 909-920.

Bova, Russell (1991) Political Dynamics of the Post-Communist Transition: A Comparative Perspective. World Politics 44(1): 113138.

Brumberg, Daniel (2002) Democratization in the Arab World? The Trap of Liberalized Autocracy. Journal of Democracy 13(4): 56-68.

Cacioppo, John, and Richard Petty (1979) Effect of Message Repetition and Position on Cognitive Response, Recall, and Persuasion. Journal of Personality and Social Psychology 37(1): 97-109.

Campbell, Donald, and Julian Stanley (1963) Experimental and QuasiExperimental Designs for Research. Chicago: Rand McNally.

Cederman, Lars-Erik, and Kristian Skrede Gleditsch (2004) Conquest and Regime Change: An Evolutionary Model of the Spread of Democratic Peace. International Studies Quarterly 48(3): 603-629.

Checkel, Jefrrey (2005) International Institutions and Socialization in Europe: Introduction and Framework. International Organization 59 (4): 801-826.

Checkel, Jefrrey, And Andrew Moravcsik (2001) A Constructivist Research Program in EU Studies? European Union Politics 2(2): 219249.
Claisse, Alain. (1987) "Makhzen Traditions and Administrative Channels." In The Political Economy of Morocco, edited by I. William Zartman, New York: Praeger.

Coок, Thomas, and Donald Campbell (1979) Quasi-Experimentation: Design and Analysis Issues for Field Settings. Chicago: Rand McNally.

Dahl, Robert (1971) Polyarchy: Participation and Opposition. New Haven: Yale University Press.

Diamond, Larry (2010) Why Are There No Arab Democracies? Journal of Democracy 21(1): 93-112.

Diamond, Alexis, and Jasjeet S. Sekhon (2013) Genetic Matching for Estimating Causal Effects: A General Multivariate Matching Method for Achieving Balance in Observational Studies. Review of Economics and Statistics 95(3): 932-945.

Doorenspleet, Renske (2004) The Structural Context of Recent Transitions to Democracy. European Journal of Political Research 43 (3): 309-335.

Eagly, Alice, and Shelly Chaiken (1993) The Psychology of Attitudes. Forth Worth, TX: Harcourt Brace Jovanovich.

Farazmand, Ali (2010) Bureaucracy and Democracy: A Theoretical Analysis. Public Organization Review 10(3): 245-258.

Finnemore, Martha (1993) International Organizations as Teachers of Norms: The United Nations Educational, Scientific, and Cultural Organization and Science Policy. International Organization 47(4): 565-597.

FlockHART, Trine (2004) 'Masters and Novices': Socialization and Social Learning through the Nato Parliamentary Assembly. International Relations 18(3): 361-380.

FreyburG, Tina (2011) Transgovernmental Networks as Catalysts for Democratic Change? EU Functional Cooperation with Arab Authoritarian Regimes and Socialization of Involved State Officials into Democratic Governance. Democratization 18(4): 1001-1025.

Freyburg, Tina, Sandra Lavenex, Frank Schimmelfennig, Tatiana Skripka, AND ANne Wetzel (2011) Democracy Promotion Through Functional Cooperation? The Case of The European Neighbourhood Policy. Democratization 18(4): 1026-1054.

Gaertner, Samuel, John Dovidio, and Betty Bachman (1996) Revisiting the Contact Hypothesis: The Induction of a Common Ingroup Identity. International Journal of Intercultural Relations 20(34): 271-290.

GHeciu, AlexAndra (2005) Security Institutions as Agents of Socialization? NATO and the 'New Europe'. International Organization 59(4): 973-1012.

Hooghe, Liesbet (2005) Several Roads Lead to International Norms, but Few Via International Socialization: A Case Study of the European Commission. International Organization 59(4): 861-898.

Hydén, Göran, Julius Court, and Kenneth Mease (2004) Making Sense of Governance. Empirical Evidence from Sixteen Developing Countries. Boulder: Lynne Rienner.

John, Oliver, and Veronica Benet-Martínez (2000) Measurement: Reliability, Construct Validation, and Scale Construction. In Handbook of Research Methods in Social and Personality Psychology, edited by Harry Reis and Charles Judd. Cambridge: Cambridge University Press.

Johnston, Alaistair Iain (2001) Treating International Institutions as Social Environments. International Studies Quarterly 45(4): 487-515.

Kampstra, Peter (2008) "Beanplot: A Boxplot Alternative for Visual Comparison of Distributions". Journal of Statistical Software 28. Code Snippet 1: 1-9.

Keohane, Robert, AND Joseph Nye (1974) Transgovernmental Relations and International Organizations. World Politics 27(1): 39-62.

Kern, Holger Lutz, and Jens Hainmueller (2009) Opium for the Masses: How Foreign Media can Stabilize Authoritarian Regimes. Political Analysis 17(4): 377-399.

Kerr, Henry (1973) Changing Attitudes through International Participation: European Parliamentarians and Integration. International Organization 27(1): 45-83.

King, Gary, James Honacker, Anne Joseph, and Kenneth Scheve (2001) Analyzing Incomplete Political Science Data: An Alternative Algorithm for Multiple Imputation. American Political Science Review 95(1): 50-69.

Kopstein, Jefrrey, and David Reilly (2000) Geographic Diffusion and the Transformation of the Postcommunist World. World Politics 53 (1): 1-37. 
Levitsky, Stephen, And Lucan Way (2005) International Linkage and Democratization. Journal of Democracy 16(3): 20-34.

Long, Theodore, AND JefFrey Hadden (1985) A Reconception of Socialization. Sociological Theory 3(1): 39-49.

Loveless, Matthew (2009) The Theory of International Media Diffusion: Political Socialization and International Media in Transitional Democracies. Studies in Comparative International Development 44(2): 118-136.

Marsden, Peter (1990) Network Data and Measurement. Annual Review of Sociology 16: 435-463.

Marsh, David (1971) Political Socialization: The Implicit Assumptions Questioned. British Journal of Political Science 1(4): 453-465.

Merritt, Richard (1972) Effects of International Student Exchange. In Communication in International Politics, edited by Richard Merritt. Urbana: University of Illinois Press.

Moore, Wilbert (1969) Occupational Socialization. In Handbook of Socialization Theory and Research, edited by David A. Goslin. Chicago: Rand McNally.

Norris, Pippa (2004) Global Political Communication: Good Governance, Human Development, and Mass Communication. In Comparing Political Communication: Theories, Cases, and Challenges, edited by Frank Esser and Barbara Pfetsch. Cambridge: Cambridge University Press.

Paolini, Stefania, Jake Harwood, And Mark Rubin (2010) Negative Intergroup Contact Makes Group Memberships Salient: Explaining Why Intergroup Conflict Endures. Personality and Social Psychology Bulletin 36(12): 1723-1738.

Pérez-Armendáriz, Clarisa, ANd David Crow (2010) Do Migrants Remit Democracy? International Migration, Political Beliefs, and Behavior in Mexico. Comparative Political Studies 43(1): 119-148.

Pettigrew, Thomas, and Linda Tropp (2000) Does Intergroup Contact Reduce Prejudice? Recent Meta-Analytic Findings. In Reducing Prejudice and Discrimination, edited by Stuart Oskamp. Mahwah, NJ: Lawrence Erlbaum Associates.

Pollack, Mark. (1998) Constructivism, Social Psychology, and Elite Attitude Change. Lessons from an Exhausted Research Program. Paper Presented at the Conference Of Europeanists, Baltimore, MD., February 26.

Pouliot, Vincent (2008) The Logic of Practicality: A Theory of Practice of Security Communities. International Organization 62(2): 257-288.

Presser, Stanley, Jennifer Rothgeb, Mick Couper, Judith Lessler, Elizabeth Martin, Jean Martin, and Eleanor Singer (eds.) (2004) Methods for Testing and Evaluating Survey Questionnaires. Hoboken, NJ: John Wiley \& Sons Inc.

Raustiala, Kal (2002) The Architecture of International Cooperation: Transgovernmental Networks and the Future of International Law. Virginia Journal of International Law 43(1): 1-92.

Risse, Thomas, Stephen Ropp, and Kathryn Siknink (eds.) (1999) The Power of Human Rights. International Norms and Domestic Change. Cambridge: Cambridge University Press.

Risse, Thomas, Stephen Ropp, and Kathryn Siknink (eds.) 2013) The Persistent Power of Human Rights. From Commitment to Compliance. Cambridge: Cambridge University Press.

ROHRSCHNEIDER, RoBERT (1996) Institutional Learning versus Value Diffusion: The Evolution of Democratic Values among Parliamentarians in Eastern and Western Germany. Journal of Politics 58(2): 422-446.
Schiappa, Edward, Peter Gregg, and Dean Hewes (2005) The Parasocial Contact Hypothesis. Communication Monographs 72(1): 92-115.

Schmitt-Beck, Rüdiger (2003) Mass Communication, Personal Communication and Vote Choice. The Filter Hypothesis of Media Influence in Comparative Perspective. British Journal of Political Science 33(2): 233-259.

Sigalas, Emmanuel (2010) Cross-Border Mobility and European Identity: The Effectiveness of Intergroup Contact during the Erasmus Year Abroad. European Union Politics 11(2): 241-265.

Simmons, Beth, Frank Dobbin, AND Geoffrey Garrett (2006) Introduction: The International Diffusion of Liberalism. International Organization 60(4): 781-810.

Slaughter, Anne-Marie, and David Zaring (2006) Networking Goes International: An Update. Annual Review of Law and Social Science 2: 211-229.

Spilimbergo, Antonio (2009) Democracy and Foreign Education. American Economic Review 99(1): 528-543.

TAjFel, Henri, AND John Turner (1979) An Integrative Theory of Intergroup Conflict. In The Social Psychology of Intergroup Relations, edited by William Austin and Stephen Worchel. Monterey, CA: Brooks/Cole.

Turner, John (1985) Social Categorization and the Self-Concept: A Social Cognitive Theory of Group Behaviour. Advances in Group Processes 2: 77-122.

Van WaArden, Frans. (1992) Dimensions and Types of Policy Networks. European Journal of Political Research 21(1-2): 29-52.

WAy, LuCAN (2005) Authoritarian State Building and the Sources of Regime Competitiveness in the Fourth Wave: The Cases of Belarus, Moldova, Russia, and Ukraine. World Politics 57(2): 231-261.

Zerhouni, SAloua (2004) Morocco: Reconciling Continuity and Change. In Arab Elites: Negotiating the Politics of Change, edited by Volker Perthes. Boulder: Lynne Rienner.

Zimbardo, Philip, And Michael Leippe (1991) The Psychology of Attitude Change and Social Influence. New York: McGraw-Hill.

Zimmerman, William (1973) Issue Area and Foreign-Policy Process: A Research Note in Search of a General Theory. American Political Science Review 67(4): 1204-1212.

\section{Supporting Information}

Additional Supporting Information may be found in the online version of this article:

Table S1. Descriptive Statistics of Variables before Multiple Imputation.

Table S2. Regression Results after Multiple Imputation (Figure 2).

Table S3. Regression Analyses with Interaction Terms after Multiple Imputation.

Table S4. Regression Results after Multiple Imputation and Matching.

Table S5. Interview Codes.

Table S6. Regression Results before Multiple Imputation (Complete-Case Analyses) 